\begin{tabular}{|c|l|}
\hline Title & Suppression of floatability of pyrite in coal processing by carrier microencapsul ation \\
\hline Author(s) & Jha, Rani Kumari Thakur; Satur, Jacqueline; Hiroyoshi, Naoki; Ito, May umi; T sunekawa, Masami \\
\hline Citation & $\begin{array}{l}\text { Fuel Processing Technology, 92(5), 1032-1036 } \\
\text { https://doi.org/10.1016/.fuproc.2010.12.028 }\end{array}$ \\
\hline Issue Date & 2011-05 \\
\hline Doc URL & http://hdl.handle.net/2115/45380 \\
\hline Type & article(author version) \\
\hline File Information & FPT92-5_1032-1036.pdf \\
\hline
\end{tabular}

Instructions for use 


\title{
Suppression of floatability of pyrite in coal processing by carrier microencapsulation
}

Rani Kumari Thakur JHA * ${ }^{1}$, Jacqueline SATUR ${ }^{1}$, Naoki HIROYOSHI ${ }^{1}$, Mayumi ITO ${ }^{1}$, and Masami

\author{
TSUNEKAWA ${ }^{1}$ \\ ${ }^{1}$ Laboratory of Mineral Processing and Resources Recycling, Graduate School of Engineering, \\ Hokkaido University, Kita 13 Nishi 8, Kita-Ku, Sapporo, Hokkaido 060-8628, Japan
}

Corresponding author: Rani - rani@eng.hokudai.ac.jp, phone \# 0117066315

RECEIVED DATE (to be automatically inserted after your manuscript is accepted if required according to the journal that you are submitting your paper to)

ABSTRACT

Carrier microencapsulation, CME, is a technique to form a thin layer of metal oxide or hydroxide on pyrite surface using a water soluble organic carrier combined with metal ions. The present study investigated the effect of $\mathrm{CME}$ using tris-catecholato complex of $\mathrm{Si}^{4+}, \mathrm{Si}(\mathrm{cat})_{3}{ }^{2-}$ on pyrite-coal separation by dynamic bubble pick-up experiments and Hallimond tube flotation experiments using coal, pyrite, and a coal-pyrite mixture. The mineral samples were treated in $0-5 \mathrm{~mol} \mathrm{~m}^{-3} \mathrm{Si}(\mathrm{cat})_{3}{ }^{2-}$ solutions at pH 4-9 at treatment times of 1-24 h. Dynamic bubble pick-up experiments showed that CME treatment 
converted the pyrite surface from hydrophobic to hydrophilic but did not affect coal's hydrophobic surface. The results of the Hallimond tube flotation experiments of a coal-pyrite mixture at $\mathrm{pH}$ 7-9 in the presence of kerosene as a collector showed that pyrite floatability was selectively suppressed after $1 \mathrm{~h}$

CME treatment with $0.5 \mathrm{~mol} \mathrm{~m}^{-3} \mathrm{Si}\left(\mathrm{cat}_{3}{ }_{3}{ }^{2-}\right.$ while both coal and pyrite were floated without the treatment. This indicates that CME treatment is effective in suppressing pyrite floatability in coal-pyrite flotation.

Keywords: Pyrite; Flotation; Microencapsulation; Surface property; Coal processing

\section{Introduction}

Pyrite, $\mathrm{FeS}_{2}$, is one of the most abundant minerals, yet economically insignificant and less desirable. It is a common gangue mineral in coal, and causes $\mathrm{SO}_{2}$ emissions during coal combustion. $\mathrm{SO}_{2}$ is one of the main constituents for acid rain formation therefore the separation of pyrite from coal before combustion is environmentally important $[1,2]$.

Dense media separation, cyclones, jigs, and froth flotation are some of the existing techniques for coal processing [3]. Gravity separation methods e.g. dense media separation, cyclones, and jigs are quite efficient in separating pyrite from coal because pyrite density $\left(\sim 5 \mathrm{~g} \mathrm{~cm}^{-3}\right)$ is much higher than that of coal $\left(1.3-1.5 \mathrm{~g} \mathrm{~cm}^{-3}\right)$. However, the efficiency of gravity separation falls rapidly for particles, finer than $100 \mu \mathrm{m}$ [1]; therefore froth flotation is used for washing of fine coal [4]. The amount of coal processed by froth flotation is about $13.6 \%$ of the total coal preparation [3]. 
In froth flotation, air bubbles are introduced into a mineral suspension. Hydrophobic minerals attach to the air bubbles and are recovered as the froth product but hydrophilic minerals remain in the suspension and are discarded to the tailing pond as the tailing. Coal is hydrophobic and is separated from hydrophilic gangue minerals e.g., pyrite in the flotation. However, the natural hydrophobic property of pyrite makes coal-pyrite separation difficult as significant amounts of pyrite are recovered in the froth along with the coal $[5,6]$.

The other problem associated with pyrite in coal is the formation of acid mine drainage or AMD in the tailing dam when pyrite is disposed as tailing from the flotation process. The disposed pyrite comes in contact with oxygen and water and is oxidized to produce sulfuric acid, which can dissolve toxic heavy metals from other minerals [7].

Relating to the above two problems (recovery of entrapped pyrite in the froth during flotation and AMD formation due to pyrite oxidation), many studies have been done in the past. To suppress pyrite floatability in flotation, the use of depressants such as sodium sulfide, potassium dichromate, potassium permanganate, ferrous/ferric sulfate, aluminum and ferric chlorides, and sodium cyanide [6,9], bacteria like Acidithiobacillus ferroxidans [8, 10], as well as several preconditioning techniques [11-12] have been reported. For controlling AMD formation, application of nonpermeable liners (e.g., clay or plastic liner in the tailing dam) and techniques to make a protective coating on pyrite 
to suppress oxidation were reported [13-16]. However, a single technique to overcome both problems simultaneously has not yet been developed.

The authors have proposed carrier microencapsulation (CME) as a new coating technique for pyrite. In CME, pyrite is immersed in aqueous solutions of an organic carrier (e.g., catechol) combined with a metal ion (e.g., $\mathrm{Ti}^{4+}$ or $\mathrm{Si}^{4+}$ ). The complex adsorbs on the pyrite surface and the organic carrier is oxidatively decomposed on pyrite. The metal ion released from the complex hydrolyzes to form a thin layer of metal oxide or hydroxide on the pyrite surface $[17,18]$. In the previous papers, it was reported that the layer formed by CME treatment is hydrophilic and protective against oxidation; therefore CME can suppress the floatability and oxidation of pyrite $[17,18]$. If CME can form a hydrophilic metal oxide/hydroxide layer on pyrite but not on coal, then it can be used as a depressant for pyrite in coal-pyrite flotation. Moreover, the proposed "Carrier micro encapsulation (CME) using tris-catecholato complex of $\mathrm{Si}_{4}{ }^{+"}$ is industrially viable, easy to handle and economical. In the case of CME treatment, it is also expected that the pyrite tailing would not be oxidized to produce AMD after disposal in the tailing dam since pyrite is encapsulated with a protective coating of metal oxide or hydroxide. Therefore, as the proposed CME treatment is equally effective in suppressing pyrite oxidation in the tailing dam, the proposed technique will cut the huge amount of expanses of aftercare / treatment for AMD-acid mine drainage problem created by the air 
oxidation of discarded pyrite.

In this study, effect of CME treatment (using tris-catecholato complex of $\mathrm{Si}^{4+}$ ) on coalpyrite separation is investigated by performing lab scale flotation test.

\section{Material and Methods}

\section{Minerals and solution preparation}

A specimen-grade pyrite (origin: Peru) was crushed and in a jaw crusher (Retsch BB51) and grounded in a ball mill, and sieved to obtain a 100-150 $\mu$ m size fraction. Just before the experiments, the pyrite was washed following the procedures reported in the literature [19]: washing with ethanol with ultrasonic vibration initially applied on the solution for $30 \mathrm{~s}$, then washing with $1 \mathrm{kmol} \mathrm{m}^{-3} \mathrm{HNO}_{3}$ to create fresh pyrite surfaces, distilled water to wash off the nitric acid, and acetone to facilitate drying, and finally vacuum drying the washed pyrite for $24 \mathrm{~h}$.

The raw coal (origin: Kushiro Coal Mine, Japan) was crushed to small pieces by a hammer and the impurities were removed by hand-picking. The coal particles were further crushed in a jaw crusher (Retsch BB51) and sieved to obtain a 100-150 $\mu \mathrm{m}$ size fraction. The coal samples were stored inside polyethylene plastic bags filled with nitrogen. The proximate and ultimate analysis of the coal sample was carried out with the equipment MICRO CORDER JM10, the result is shown in table 1(A) and 1(B). 
The tris-catecholato complex of $\mathrm{Si}^{4+}\left[\mathrm{Si}(\mathrm{cat})_{3}{ }^{2-}\right]$ for CME treatment was prepared by mixing $0.142 \mathrm{~g}$ of $\mathrm{Na}_{2} \mathrm{SiO}_{3} \cdot 9 \mathrm{H}_{2} \mathrm{O}$ and $0.165 \mathrm{~g}$ of catechol in $10 \mathrm{~cm}^{3}$ distilled water. This solution contains $5 \mathrm{~mol} \mathrm{~m}{ }^{-3} \mathrm{Si}(\mathrm{cat})_{3}{ }^{2-}$. Solutions containing known concentrations of $\mathrm{Si}(\mathrm{cat})_{3}{ }^{2-}$ were prepared by diluting the $5 \mathrm{~mol} \mathrm{~m}^{-3} \mathrm{Si}(\mathrm{cat})_{3}{ }^{2-}$ solution with distilled water. The solution pHs were maintained by adding $\mathrm{HCl}$ or $\mathrm{NaOH}$ solution.

\section{CME treatment}

CME treatment was done in a $50 \mathrm{~cm}^{3}$ Erlenmeyer flask containing $1 \mathrm{~g}$ of the mineral sample ( $1 \mathrm{~g}$ pyrite, $1 \mathrm{~g}$ coal, or $0.5 \mathrm{~g}$ pyrite- $0.5 \mathrm{~g}$ coal mixture) and $10 \mathrm{~cm}^{3}$ of Si(cat) ${ }_{3}{ }^{2-}$. The flask was shaken in a water bath shaker under aerobic conditions at $25^{\circ} \mathrm{C}$ for a required treatment time. The shaking amplitude of the water bath shaker was $4 \mathrm{~cm}$ and the frequency was $120 \mathrm{~min}^{-1}$. After the required time of shaking, the flask was removed from the shaker and the contents used for the dynamic bubble pick-up experiments and flotation experiments.

\section{Dynamic bubble pick-up experiment}

Dynamic bubble pick-up experiments [20] for the CME-treated pyrite or coal were conducted using an electronic induction timer (MCT-100). The CME-treated mineral along with the solution was transferred from the Erlenmeyer flask to a rectangular optical 
glass cell to form a bed of particles. Inside the cell, an air bubble was formed at the tip of the capillary glass, and the bubble was brought into contact with the mineral particles at various contact times. The experiments were carried out at constant amplitude of the capillary motion for bubble pick-up, and the contact time between particles and air bubble was 1,000 ms unless specified. Ten bubble pick-up trials were conducted on different spots of the bed. The attachment of the mineral particles to the air bubble was observed with the help of a microscope connected to a computer display. The probability of attachment of the particles to an air bubble was calculated as the number of times the particle attached to the air bubble over the total number of bubble pick-up trials. The effect of $\mathrm{pH}, \mathrm{CME}$ treatment time, and $\mathrm{Si}(\mathrm{cat})_{3}{ }^{2-}$ concentration on the attachment of the mineral particles to an air bubble was investigated.

\section{Flotation experiments}

Lab-scale flotation experiments for pyrite, coal, and a coal-pyrite mixture were done using a Hallimond tube [21,22]. CME treatment was applied to the mineral using 0.5 mol $\mathrm{m}^{-3} \mathrm{Si}(\mathrm{cat})_{3}{ }^{2-}$ solution at natural $\mathrm{pH}$ for $1 \mathrm{~h}$. The CME-treated mineral with solution was transferred to a beaker containing $100 \mathrm{~cm}^{3}$ distilled water and stirred for 2 min using a magnetic stirrer. Afterwards, $0.278 \mathrm{~cm}^{3}$ of a kerosene-water emulsion (kerosene content: $625 \mathrm{ppm}$ ) was added as a flotation collector, and stirring was continued for $5 \mathrm{~min}$. The 
mixture was transferred to the Hallimond tube, and flotation was conducted for 5 min by supplying air at a flow rate of $100 \mathrm{~cm}^{3} \mathrm{~min}^{-1}$. The froth and tailings were recovered by filtration, washed with distilled water, transferred into drying bottles, and dried at $105^{\circ} \mathrm{C}$.

From the weight of the dried froth and tailing products, the percentage recovery of the mineral in the froth was calculated. In the coal-pyrite mixture flotation experiments, pyrite and coal in the froth and tailing products were separated by using a dense medium (41 wt\% sodium tungstate solution of specific gravity 1.5).

\section{RESULTS AND DISCUSSION}

Catechol (1, 2-dihydroxybenzene) is a bidentate chelating agent and has a remarkable affinity for metal ions in high oxidation states or with high charge/radius ratios. The studies involves catechol forming coordination compounds with silicon, triscatecholato silicate complex ion or $\mathrm{Si}(\mathrm{cat})_{3}{ }^{2-}$ are well-documented in the literature [23, 24]. In the present study, catechol was selected as the organic carrier and Si as the metal ion to form tris-catecholato silicate complex ion or $\mathrm{Si}(\mathrm{cat})_{3}{ }^{2-}$ to form a $\mathrm{SiO}_{2} / \mathrm{Si}(\mathrm{OH})_{4}$ coating on the pyrite surface to prevent pyrite floatability and oxidation.

The dynamic bubble pick-up experiments for pyrite and coal with and without CME treatment was carried out to evaluate the effects of CME on the surface wettability 
of these minerals. To optimize the conditions for CME treatment, the effect of the concentration of $\mathrm{Si}\left(\mathrm{cat}_{3}{ }_{3}{ }^{2-}, \mathrm{pH}\right.$, and treatment time were investigated.

Pyrite and coal particles were treated in different concentrations of $\mathrm{Si}(\mathrm{cat})_{3}{ }^{2-}$ solution for $1 \mathrm{~h}$ at $\mathrm{pH} 7 \sim 9$, and the effect of the concentration on the attachment probability of the mineral particle to an air bubble was investigated. As shown in Fig. 1, the attachment probability of pyrite to an air bubble decreased drastically with increasing $\mathrm{Si}(\mathrm{cat})_{3}{ }^{2-}$ concentration, and it became almost zero when the concentration was over 0.5 mol m${ }^{-3}$. The decrease in the probability of attachment was only observed for the coal at $\mathrm{Si}(\mathrm{cat})_{3}{ }^{2-}$ concentrations greater than $0.5 \mathrm{~mol} \mathrm{~m}^{-3}$ (probabilities of attachment were over 0.9 at $0-0.05 \mathrm{~mol} \mathrm{~m}^{-3}$ concentrations). At the highest concentration of $5 \mathrm{~mol} \mathrm{~m}^{-3}$, the probability of attachment of coal to an air bubble decreased to 0.7 . Based on this result, the concentration of $\mathrm{Si}(\mathrm{cat})_{3}{ }^{2-}$ for further experiments was kept at $0.5 \mathrm{~mol} \mathrm{~m}^{-3}$.

The effect of CME treatment time on the attachment probabilities of pyrite and coal with and without CME treatment using $0.5 \mathrm{~mol} \mathrm{~m}^{-3} \mathrm{Si}\left(\mathrm{cat}_{3_{3}}{ }^{2-}\right.$ was evaluated (Fig. 2). The attachment probabilities of pyrite particles shaken in distilled water (pyrite without CME) were over 0.8 at all times tested, showing that pyrite is hydrophobic. When pyrite was treated with $0.5 \mathrm{~mol} \mathrm{~m}^{-3} \mathrm{Si}(\mathrm{cat})_{3}{ }^{2-}$, the attachment probability became less than 0.1 after $1 \mathrm{~h}$ treatment, indicating that $\mathrm{Si}\left(\mathrm{cat}_{3}{ }^{2-}\right.$ effectively converts the pyrite surface from hydrophobic to hydrophilic within a short time. The attachment probabilities of coal 
without CME treatment were above 0.9 at all times tested. With CME treatment, the attachment probabilities of coal decreased with time and remained at 0.6 even after $24 \mathrm{~h}$. This indicates that with long time CME treatment, the coal wettability becomes affected by the CME treatment but the hydrophilic effect is not as great as for pyrite.

Fig. 3 illustrates the effect of $\mathrm{pH}$ on the attachment probability of CME-treated pyrite and coal to an air bubble. The conditions were $0.5 \mathrm{~mol} \mathrm{~m}^{-3} \mathrm{Si}(\mathrm{cat})_{3}{ }^{2-}$ and $1 \mathrm{~h}$ treatment time. The attachment probabilities of pyrite were less than 0.3 but the attachment probabilities of coal were higher than 0.8 over a wide $\mathrm{pH}$ range of 2-9. Especially in the $\mathrm{pH}$ range 4-9, the attachment probabilities of pyrite were zero and that of coal were over 0.9 , indicating that CME treatment can be applied for separating pyrite from coal over a wide $\mathrm{pH}$ range.

Considering the results of the dynamic bubble pick-up experiments, experimental conditions of $\mathrm{pH} 7-9$, treatment time of $1 \mathrm{hr}$, and $\mathrm{Si}(\mathrm{cat})_{3}{ }^{2-}$ concentration of $0.5 \mathrm{~mol} \mathrm{~m}{ }^{-3}$ were applied in the Hallimond tube flotation experiments. Figs. 4, 5, and 6 show the results for coal, pyrite, and the coal-pyrite mixture with and without CME treatment, respectively. Kerosene, a common flotation collector for coal, was used in the flotation experiments to evaluate the effect of CME treatment on pyrite and coal floatability in the presence of a collector. 
Fig. 4 shows the effect of CME on coal recovery in the froth in the Hallimond tube flotation experiments. Without CME treatment, the coal recovery was $82 \%$ in the absence of kerosene the addition of kerosene increased the recovery and coal recovery was $89 \%$. After applying CME treatment, more than $85 \%$ of coal was recovered in the presence and absence of kerosene. This shows that CME treatment induces no suppressive effect on coal flotation.

Fig. 5 shows the effect of CME treatment on pyrite recovery in the froth in the absence and presence of kerosene. Without CME treatment, pyrite recovery in the froth was $21 \%$ in the absence of kerosene and $72 \%$ in the presence of kerosene. With CME treatment, pyrite recovery in the froth was only $1 \%$ without kerosene and $8 \%$ with kerosene. This shows that CME treatment converts the pyrite surface from hydrophobic to hydrophilic, and the hydrophilic effect is strong as evidenced by the low recovery of pyrite in the froth even in the presence of kerosene.

Fig. 6 shows the effect of CME treatment on the flotation of coal-pyrite mixture in the presence of kerosene. Coal floatability was unaffected by the CME treatment while pyrite floatability was significantly suppressed: coal recovery in the froth was more than 90\% with or without CME treatment while pyrite recovery in the froth was $60 \%$ without CME treatment and 18\% with CME treatment. This indicates that CME treatment is able to suppress pyrite floatability selectively in coal-pyrite flotation. 
The above results imply that a hydrophilic $\mathrm{SiO}_{2}$ or $\mathrm{Si}(\mathrm{OH})_{4}$ layer was formed on the pyrite but not on the coal. The selective layer formation is assumed to be due to the differences in the electrical conductivities of pyrite and coal: pyrite is a semiconductor but coal is an insulator. A hydrophilic $\mathrm{SiO}_{2}$ or $\mathrm{Si}(\mathrm{OH})_{4}$ coating is formed on the pyrite surface as follows $[17,18]$ : the $\operatorname{Si}(\text { cat })_{3}{ }^{2-}$ complex adsorbs on the anodic site of the pyrite surface and decomposes into quinone and $\mathrm{Si}^{4+}$ ion, according to:

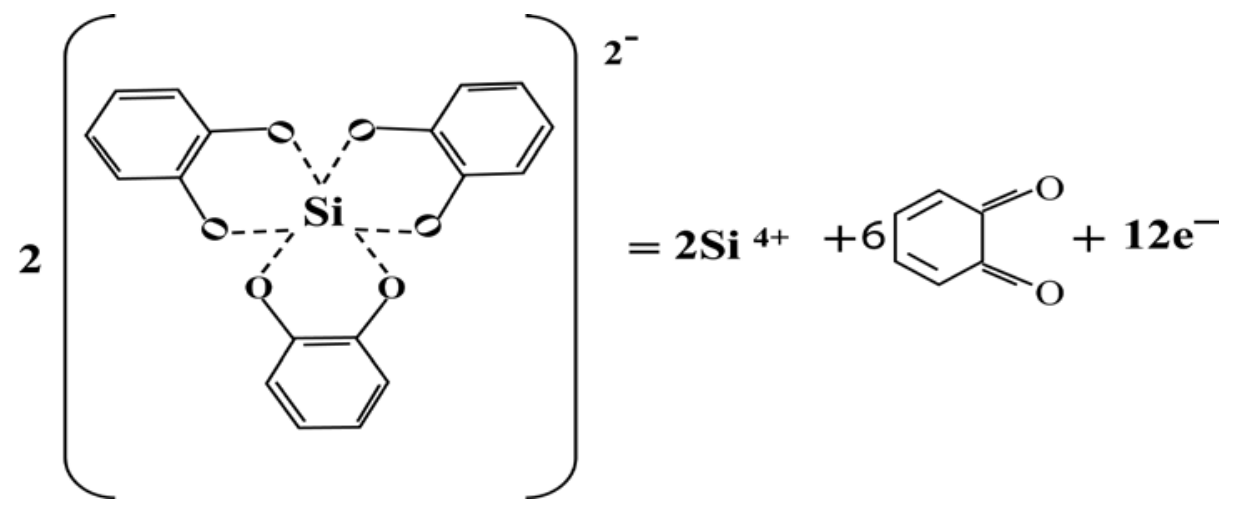

The electrons released are consumed by dissolved oxygen at the cathodic site of the pyrite:

$$
\mathrm{O}_{2}+4 \mathrm{H}^{+}+4 \mathrm{e}^{-}=2 \mathrm{H}_{2} \mathrm{O}
$$

The $\mathrm{Si}^{4+}$ ion released by the reaction in Eq. 1 hydrolyzes with water to form an $\mathrm{SiO}_{2}$ or $\mathrm{Si}(\mathrm{OH})_{4}$ layer on the pyrite surface:

$$
\begin{aligned}
& \mathrm{Si}^{4+}+4 \mathrm{H}_{2} \mathrm{O}=\mathrm{Si}(\mathrm{OH})_{4}+4 \mathrm{H}^{+} \\
& \mathrm{Si}(\mathrm{OH})_{4}=\mathrm{SiO}_{2}+2 \mathrm{H}_{2} \mathrm{O}
\end{aligned}
$$


Summing up the anode, cathode, and hydrolysis reactions (Eqs. 1-4) give the overall reactions (Eqs. 5-6):
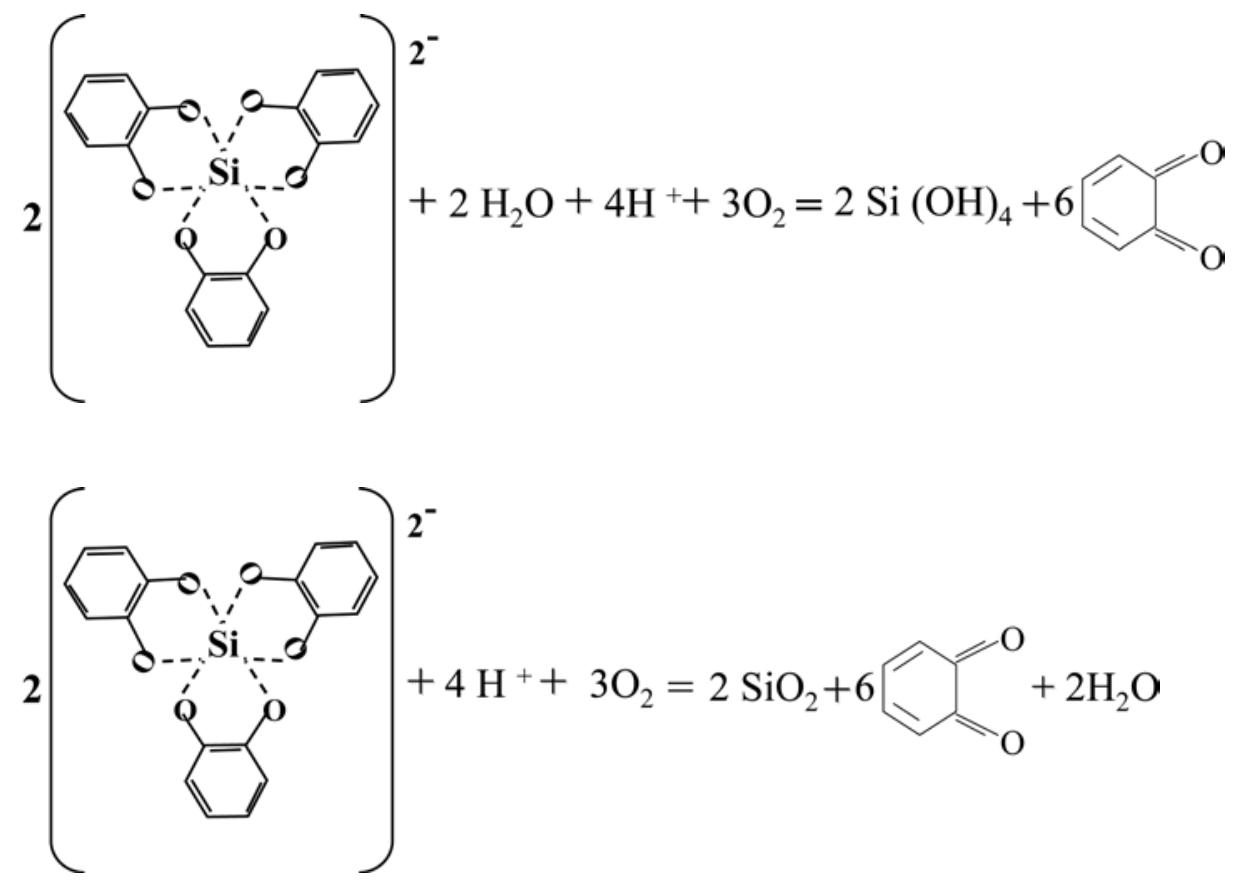

On the other hand, the $\mathrm{Si}(\mathrm{cat})_{3}{ }^{2-}$ complex does not decompose on the coal surface because coal is an insulator. As a result, no hydrophilic coating is formed on the coal surface thus coal floatability is not affected. Although the details of the above mechanism are not confirmed yet and further investigation is needed, the results in the present study show that $\mathrm{CME}$ using $\mathrm{Si}(\mathrm{cat})_{3}{ }^{2-}$ is effective in suppressing pyrite floatability in coal flotation.

\section{CONCLUSION}

The effect of carrier microencapsulation (CME) treatment using a Si-catechol 
complex $\left(\mathrm{Si}(\mathrm{cat})_{3}{ }^{2-}\right)$ on coal-pyrite wettability and floatability was investigated through bubble pick-up experiments and Hallimond tube flotation experiments. The results of bubble pick-up experiments showed that CME treatment changed the hydrophobic pyrite surface to hydrophilic but did not change coal's hydrophobic surface over a wide range of conditions: $\mathrm{pH} 4-9$, treatment times of $1-24 \mathrm{~h}$, and $\mathrm{Si}(\mathrm{cat}){ }_{3}{ }^{2-}$ concentrations of $0.5-5$ mol m${ }^{-3}$. The Hallimond tube flotation experiments of a coal-pyrite mixture showed that pyrite floatability was selectively suppressed even in the presence of kerosene as collector.

\section{References}

(1) M.C. Fuerstenau, G. Jameson, R.H. Yoon, Froth flotation - a Century of Innovation, Society for Mining, Metallurgy and Exploration, Inc. (SME), Littleton, Colorado, USA, 2007.

(2) J. Gasiorek, Waste pyritic coal as a raw material for energetic industry, Fuel Processing Technology, 52 (1997) 175-182.

(3) R. Kempnich, Coal Preparation - a World View, Proceedings of the $17^{\text {th }}$ International Coal Preparation Exhibition and Conference, Lexington (2000) 5-48.

(4) D.W. Fuerstenau, R. Jia, G.H. Harris, An improved class of universal collectors for 
the flotation of oxidized and/or low-rank coal, International Journal of Mineral Processing, 58 (2000) 99-118.

(5) Y. Hu, G. Qiu, S. Sun, D. Wang, Recent development in researches of electrochemistry of sulfide floatation at Central South University of Technology, Transaction of Nonferrous Metals Society of China, 10 (2000) 1-7.

(6) S.K. Kawatra, T.C. Eisele, Pyrite recovery mechanisms in coal flotation, International Journal of Mineral Processing, 50 (1997) 187-201.

(7) A. Ata, K. Soner, Acid Mine Drainage (AMD): causes, treatment and case studies, Journal of Cleaner Production, 14 (2006) 1139-1145.

(8) Y.A. Attia, M.A. Elzeky, Coal desulfurization using bacteria adaptation and bacterial modification of pyrite surface, US Patent 4775627, 1988.

(9) S.K. Mishra, R.R. Klimpel (Eds.), Fine Coal Processing, Noyes Publications, park Ridge, New Jersey, 1987.

(10) J.D. Miller, Y. Ye, R. Jin, Improved pyrite rejection by chemically-modified fine coal flotation, International Journal of Coal Preparation and Utilization, 6 (1989) 151166.

(11) H. Zhu, An investigation of pyrite depression in coal flotation by electrochemical 
pyrite surface control, Fuel and Energy Abstracts, 38 (1997) 192.

(12) W. Kang, H. Xun, J.Chen, Study of enhanced fine coal de-sulphurization and deashing by ultrasonic flotation, Journal of China University of Mining \& Technology, 17 (2007) 358-362.

(13) N. Kafui, N.O. Egiebor, Control of pyrite oxidation by phosphate coating, The Science of The Total Environment, 162 (1995) 225-237.

(14) P.M. Healey, A.M. Robertson, A case history of an acid generation abatement program for an abandoned copper mine, Geological Aspects of Tailing Disposal and Acid Mine Drainage, The Vancouver Geotechnical Society, Vancouver, May 26, 1989.

(15) V.P. Evangelou, Pyrite Microencapsulation Technologies: Principles and Potential field Application, Ecological Engineering, 17 (2001) 165-178.

(16) D.B. Johnson, K.B. Hallberg, Acid Mine Drainage remediation options: a review, Science of the Total Environment, 338 (2005) 3-14.

(17) J. Satur, N. Hiroyoshi, M. Tsunekawa, M. Ito, H. Okamoto, Carriermicroencapsulation for preventing pyrite oxidation, International Journal of Mineral Processing, 83:3-4 (2007) 116-124.

(18) R.K.T. Jha, J. Satur, N. Hiroyoshi, M. Ito, M. Tsunekawa, Carrier- 
microencapsulation using Si-catechol complex for suppressing pyrite floatability, Minerals Engineering, 21:12-14 ( 2008) 889-893.

(19) K. Sasaki, M. Tsunekawa, T. Ohtsuka, H. Konno, Confirmation of a sulfur-rich layer on pyrite after oxidative dissolution by $\mathrm{Fe}(\mathrm{III})$ ions around $\mathrm{pH} 2$, Geochimica et Cosmochimica Acta, 59 (1995) 3155-3158.

(20) R. Yoon, J.L. Yordan, Induction time measurements for the quartz-amine flotation system, Journal of Colloid and Interface Science, 141 (1991) 374-383.

(21) D.W. Fuerstenau, P.H. Metzger, G.D. Seele, How to use this modified Hallimond tube for better flotation testing, Engineering and Mining Journal, 158 (1957), 93-95.

(22) B. A. Wills, Mineral processing technology: An introduction to the practical aspects of ore treatment and mineral recovery, seventh ed., Elsevier, Butterworth Heinemann, London 2006, page. 289

(23) M.J. Caulfield, T. Russo, D.H. Solomon, Complexes of benzene-1,2-diol mannich bases, Novel hexacoordinate zwitterionic silicon (IV), Australian Journal of Chemistry, 54:6 (2001) 375-381.

(24) P. Kansal, R.M. Laine, Pentacoordinate silicon complexes as precursors to silicategrasses and ceramics, Journal of the American Ceramic Society, 77:4 (1994) 875-882. 
Figures and Captions :

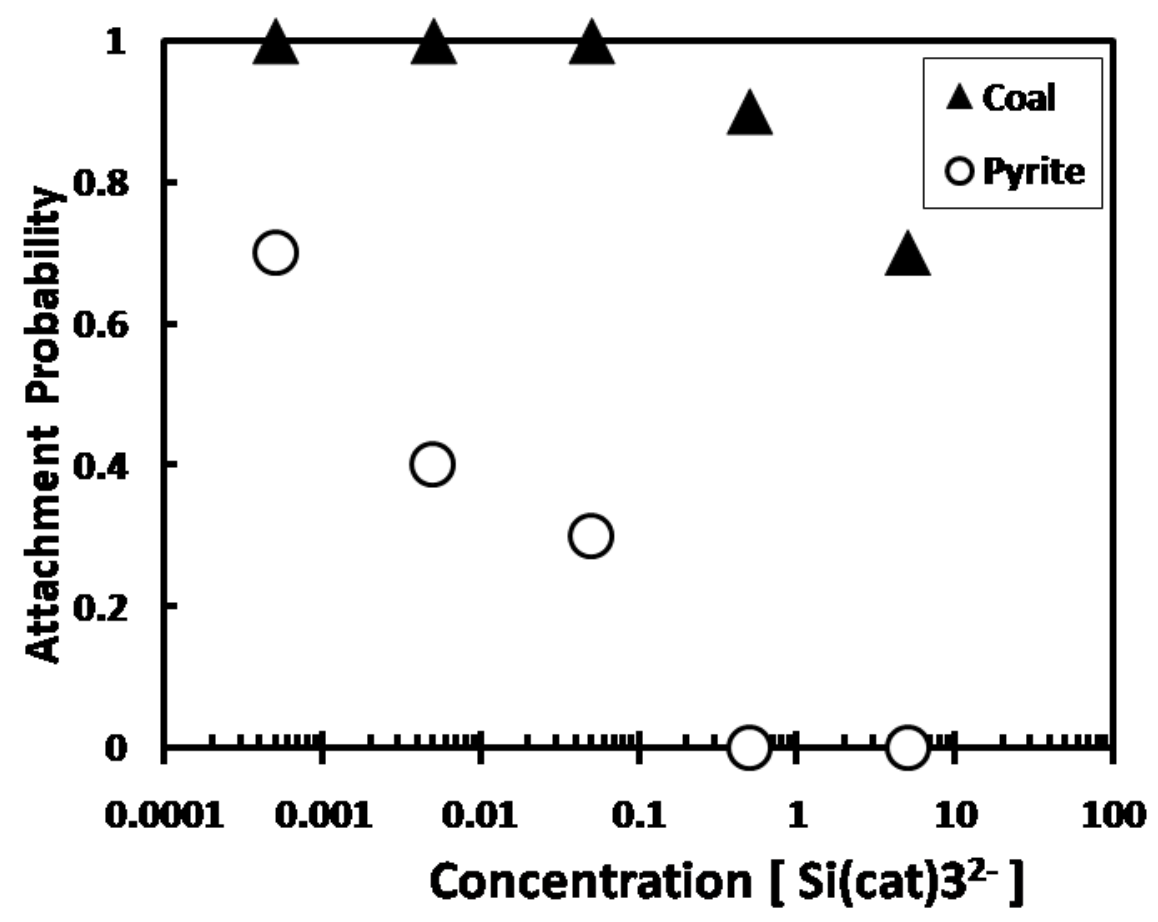

Fig: 1 Effect of concentration of Si(cat $)_{3}{ }^{2-}$ on attachment probability of pyrite and coal particle to air bubble in dynamic bubble pick up experiments. CME treatment time was 1 hr. $\mathrm{pH}$ of the $\mathrm{Si}(\mathrm{cat})_{3}{ }^{2-}$ was 7 to 9 . 


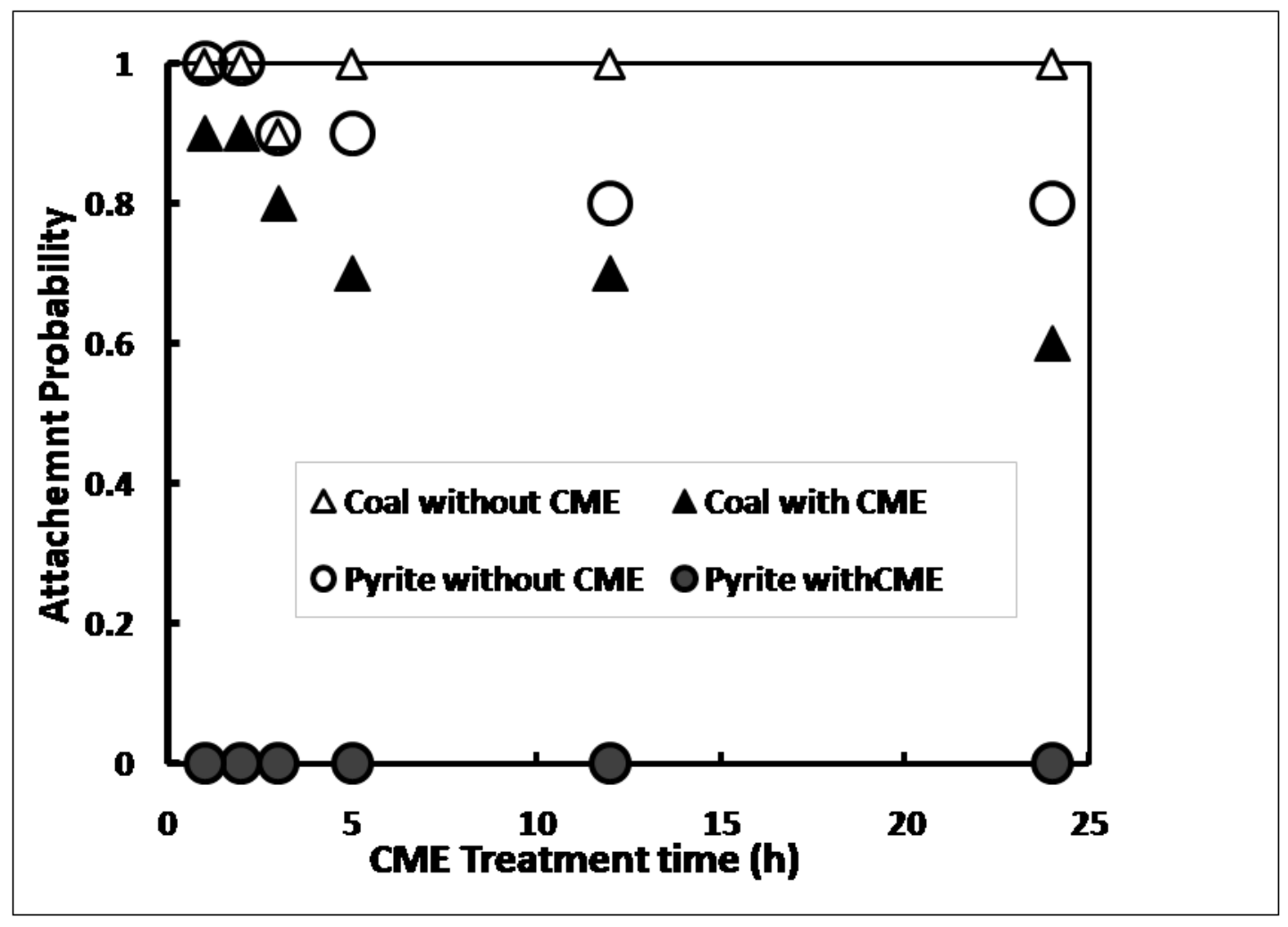

Fig: 2 Effect of CME treatment time on attachment probability of pyrite and coal particle to air bubble with /without CME in dynamic bubble pick up experiments. $\mathrm{Si}(\mathrm{cat})_{3}{ }^{2-}$ concentration was $0.5 \mathrm{~mol} \mathrm{~m}^{-3,} \mathrm{pH}$ of the $\mathrm{Si}(\mathrm{cat})_{3}{ }^{2}$ was 7 to 9 .

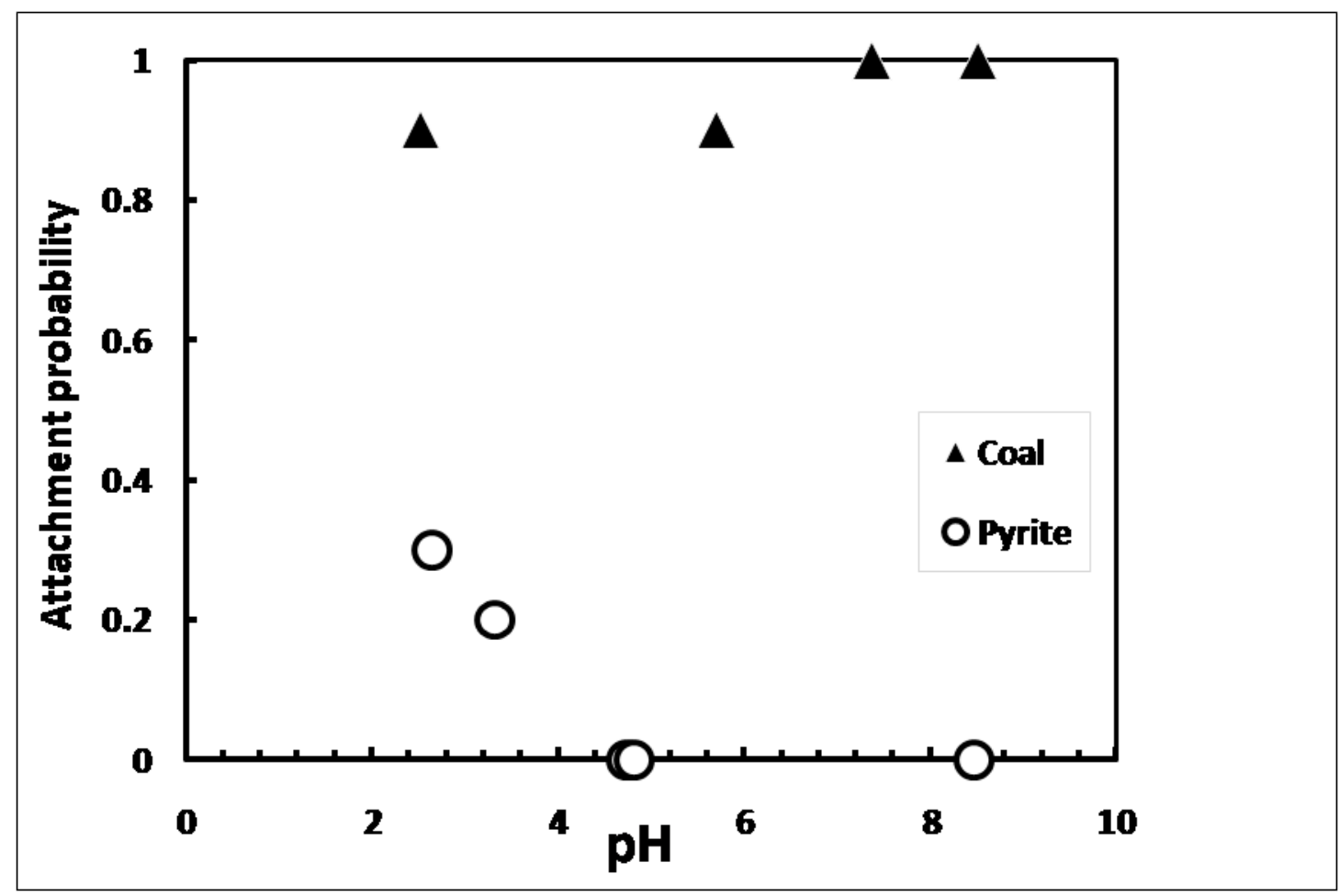


Fig: 3 Effect of $\mathrm{pH}$ on attachment probability of pyrite and coal particle to air bubble in dynamic bubble pick up experiments. Si(cat) ${ }_{3}{ }^{2-}$ concentration was $0.5 \mathrm{~mol} \mathrm{m^{-3 }}$. CME treatment time was 1 hour.

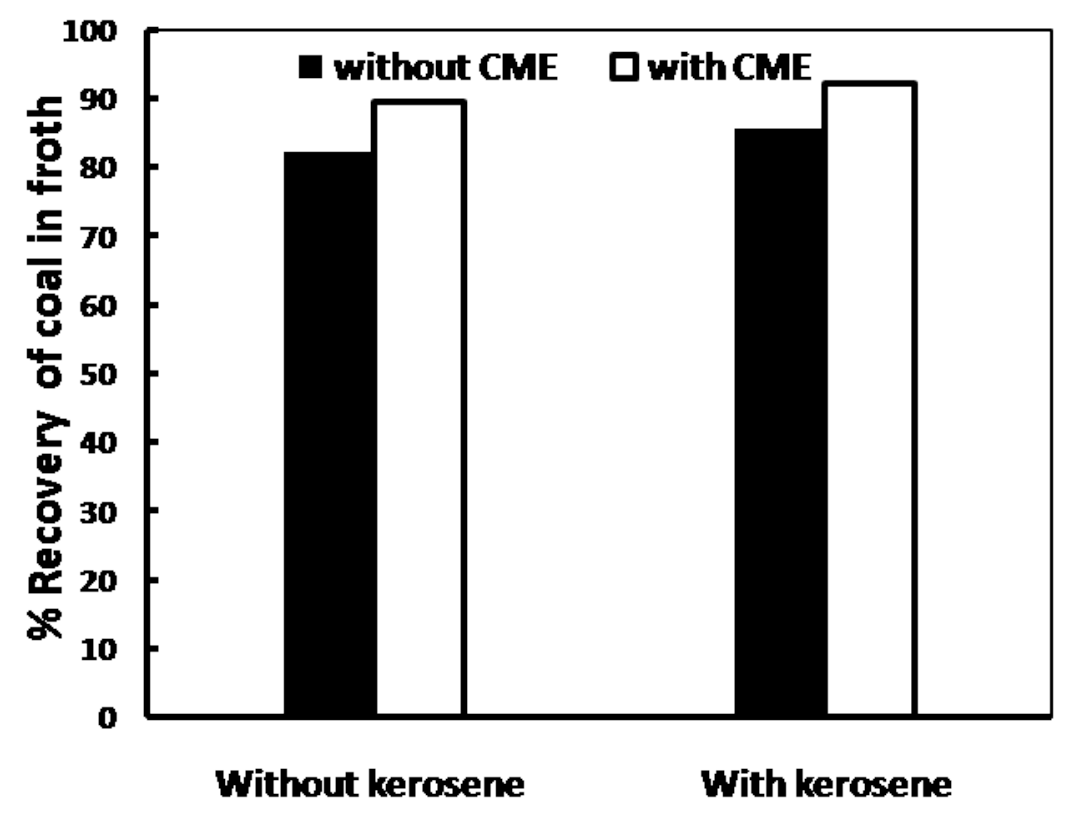

Fig: 4 Effect of CME treatment on coal recovery in froth in presence or absence of 0.278 $\mathrm{cm}^{3}$ of $625 \mathrm{ppm}$ kerosene. The $\mathrm{Si}(\mathrm{cat})_{3}{ }^{2-}$ concentration: $0.5 \mathrm{~mol} \mathrm{~m}^{-3}, \mathrm{pH}: 7-9, \mathrm{CME}$ treatment time: $1 \mathrm{~h}$. 


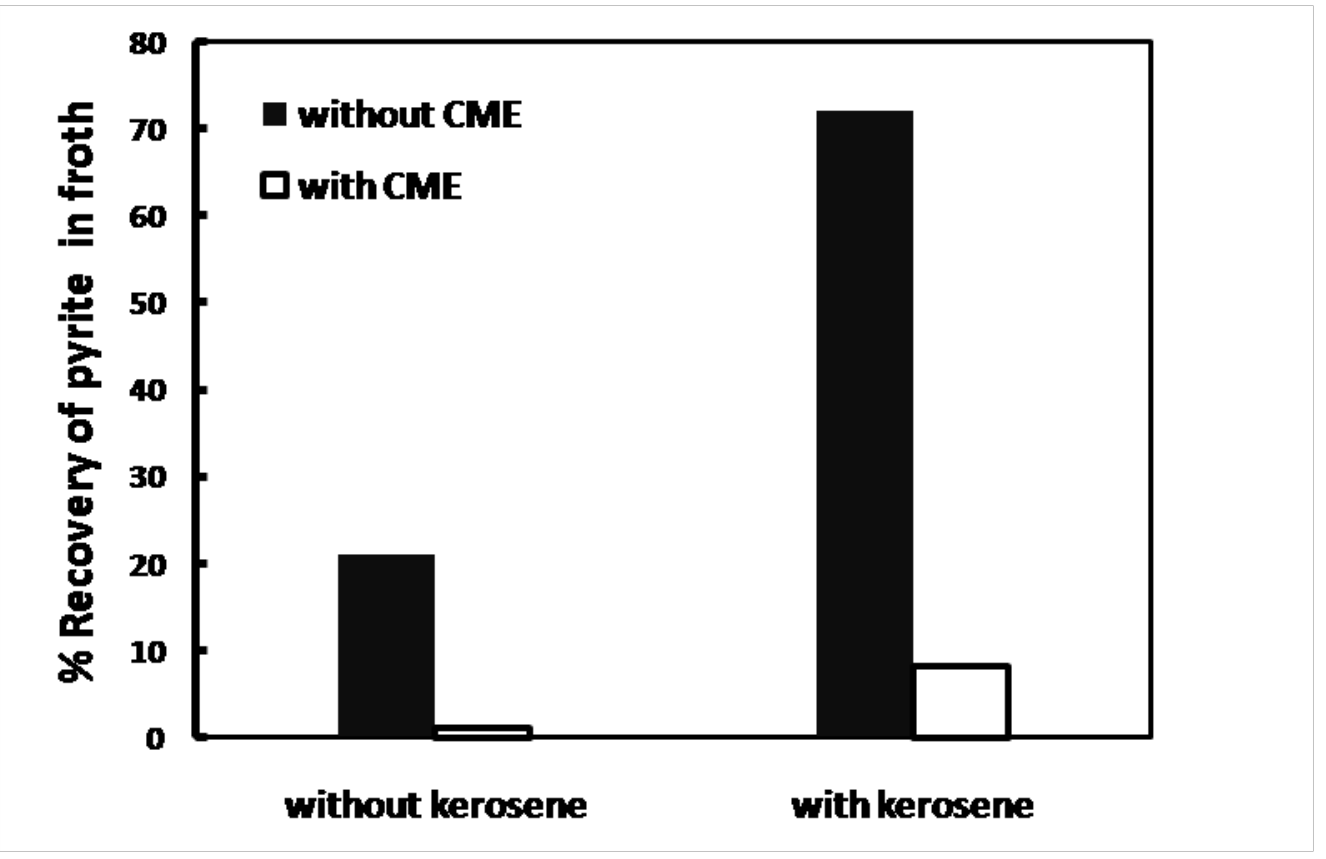

Fig: 5 Effect of CME on recovery of pyrite in froth in the presence or absence of 0.278 $\mathrm{cm}^{3}$ of $625 \mathrm{ppm}$ kerosene. The $\mathrm{Si}(\mathrm{cat})_{3}{ }^{2-}$ concentration: $0.5 \mathrm{~mol} \mathrm{~m}^{-3}, \mathrm{pH}: 7-9$, CME treatment time: $1 \mathrm{~h}$. 


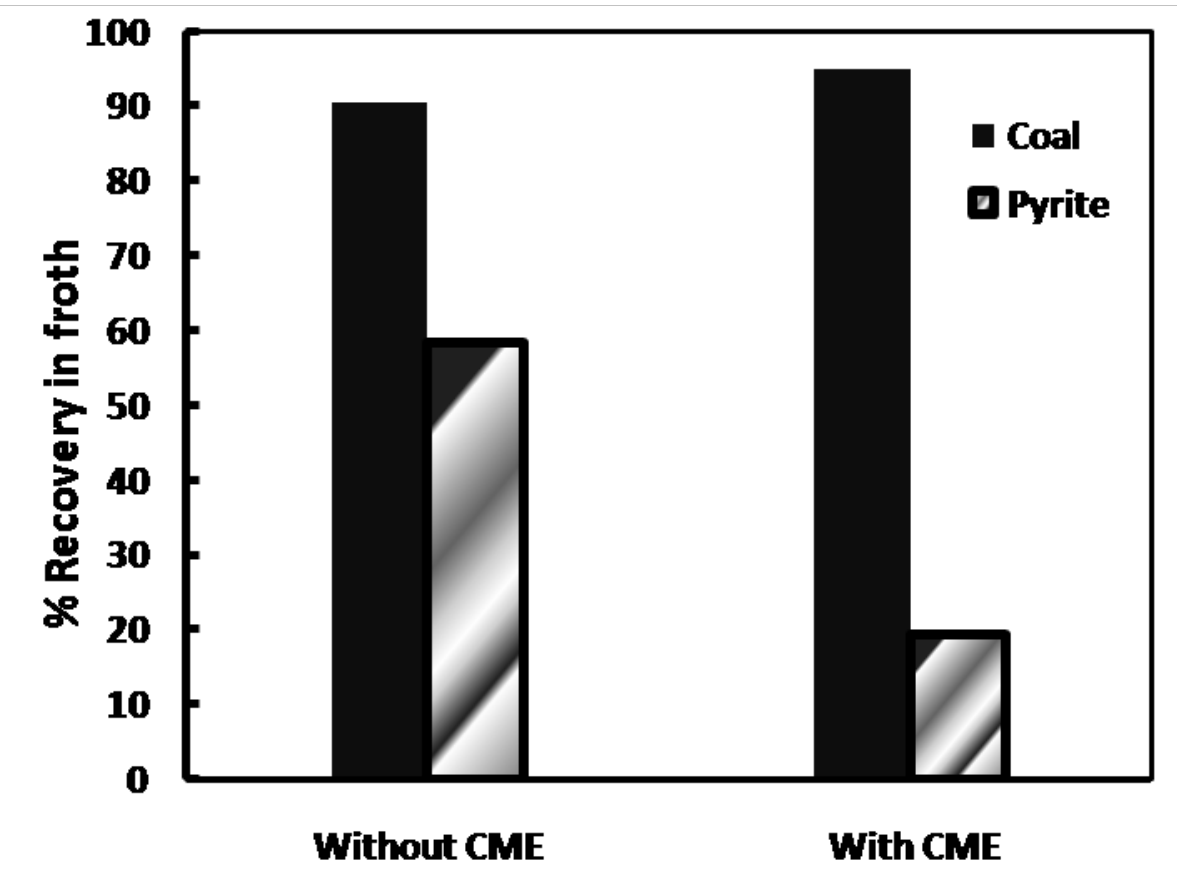

Fig: 6 Effect of CME treatment on flotation of the coal-pyrite mixture in the presence of $0.278 \mathrm{~cm}^{3}$ of $625 \mathrm{ppm}$ kerosene. The $\mathrm{Si}(\mathrm{cat})_{3}{ }^{2-}$ conc: $0.5 \mathrm{~mol} \mathrm{~m}{ }^{-3}, \mathrm{pH}: 7-9, \mathrm{CME}$ treatment time: $1 \mathrm{~h}$.

\begin{tabular}{|c|c|}
\hline Component & Weight,\% \\
\hline Moisture & 5.6 \\
\hline Ash & 7.8 \\
\hline Volatilematter & 43.4 \\
\hline Fixedcarbon & 43.2 \\
\hline Total & 100.0 \\
\hline
\end{tabular}

Table:1 (A) Proximate analysis of the Kushiro coal sample 


\begin{tabular}{|c|c|}
\hline Elements & Weight,\% \\
\hline C & 72.54 \\
\hline H & 6.19 \\
\hline N & 1.21 \\
\hline S & 0.58 \\
\hline O & 19.48 \\
\hline Total & 100.00 \\
\hline
\end{tabular}

Table:1 (B) Ultimate analysis of the Kushiro coal sample 